\title{
The recovery of the ostracod fauna after the Late Devonian mass extinction: the Devils Gate Pass section example (Nevada, USA)
}

\author{
Le renouvellement de la faune d'Ostracodes après l'extinction en masse du \\ Dévonien supérieur : l'exemple de la coupe du col de Devils Gate (Nevada, USA) \\ Jean-Georges Casier $^{a *}$, Francis Lethiers ${ }^{b}$ \\ a Département de paléontologie, Institut royal des sciences naturelles de Belgique, 29, rue Vautier, 1000 Bruxelles, Belgique \\ ' ${ }^{2}$ Laboratoire de micropaléontologie, départernent de géologie sédimentaire, université Paris 6, T25-15, 4E, case 104, 4, place \\ Jussieu, 75252 Paris cedex 05, France
}

\begin{abstract}
The recovery of the ostracod fauna is rapid after the Late Devonian mass extinction in the Devils Gate Pass section and fifty-nine species have been recognised in the Early Famennian. Forty-five appear for the first time, whereas fourteen others are known from the Late Trasnian (= lazarus species). The ostracod distribution in the Early Tamennian at Devils Gate is greatly influenced by regional sedimentological factors principally induced by a drastic sea-level eustatic fall. (@ Académie des sciences / Elsevier, Paris.)
\end{abstract}

\section{Ostracods / Frasnian-Famennian boundary / recovery / Nevada}

Résumé - Le renouvellenuent faunique des Ostracodes s'opère rapidement après l'extinction du Dévonien supérieur dans la coupe du col de Devils Gate, au Nevada. Parmi les 59 espèces reconnues, 45 apparaissent pour la première fois et 14 autres sont déjà connucs du Frasnien (= espèces lazares). La distribution des Ostracodes dans la partie inférieure du Famennien de Devils Gate est fortement influencée par des facteurs sédimentologiques locaux. induits par une brusque régression marine. (c) Académie des sciences / Flsevier, Paris.)

Ostracodes / Limite Frasnien-Famennien / reconquête / Nevada.

\section{Version abrëgée (voir p. 506)}

\section{Introduction}

The Late Devonian is marked by one of the five largest mass extinctions of the Phanerozoic (Raup and Sepkoski, 1982; Sepkoski, 1990), responsible for the disappearance of the most extensive reef development this planet has ever seen (Copper, 1994). The most affected species were reefal, perireefal and shallow-water benthic organisms, especially corals, stromatoporoids, trilobites and brachiopods. Recently, McGhee (1996) reviewed the many theo- ries that have been presented to explain this catastrophic event which happened, more precisely, at the FrasnianFamennian boundary (FFB).

Ostracods are very ecologically sensitive crustaceans and they provide an useful tool for the analysis of the Frasnian-Famennian crisis. Their study in the FFB Coumiac global stratotype section and point (GSSP) in the Montagne Noire (Southern France) (Lethiers and Casier, 1996), in the Schmidt quarry, an auxiliary reference section for the FFB, in the Kellerwald (Germany) (Casier and

Note présentée par Jean Dercourt.

Note remise le 22 juin 1998, acceptée après révision le 9 septembre 1998.

*E-mail: casier.pal@kbinirsnb.be 
Lethiers, 1998a) and in the Devils Gate Pass section in Nevada (USA) (Casier et al., 1996) proves, for instance, that the mass extinction, which wiped out more than $75 \%$ of all marine ostracod species, was an abrupt event at least in lower latitudes.

Until now, no precise data existed about the recovery and the diversification of ostracods after the Late Devonian mass extinction. This first study provides valuable information about this catastrophic event at Devils Gate.

\section{The Devils Gate Pass section}

The Devils Gate Pass section (N 39³4'518; W $116^{\circ} 04^{\prime} 024$ ) is considered as one of the most important reference sections worldwide for the FFB. This section is located $100 \mathrm{~m}$ north of U.S. highway $50,13 \mathrm{~km}$ west of the mining town of Eureka, in Eureka County, Nevada (figure 1). The lithology, the sedimentology and conodonts have been studied by Sandberg and Poole (1977) and Sandberg et al. $(1988,1989,1997)$. The FFB is located in the upper member of the Devils Gate Limestone (figure 2), which consisls of deep-water slope deposits, mainly debris-flow and turbiditic limestones.

Ostracods are very abundant and diversified in the uppermost Frasnian beds at Devils Gate. Seventy ostracod species have been identified in the Latest Frasnian linguiformis conodont zone (Casier and Lethiers, 1998b). They belong to the Eifelian ecotype of Becker (in Bandel and Becker, 1975) and are indicative of a well oxygenated marine environment below wave base, probably on the outer platform. Of the seventy species occurring in the Late Frasnian at Devils Gate, only sixteen survived the mass extinction, twelve at Devils Gate and four in other sections. These 'lazarus' species have been figured in Casier et al. (1996) and Casier and Lethiers (1997).

For the present study, eighteen samples (DVG10DVG27) were collected in the Famennian of the Devils Gate Pass section (figure 2). Using the hot acetolysis method (Lethiers and Crasquin-Soleau, 1988), about

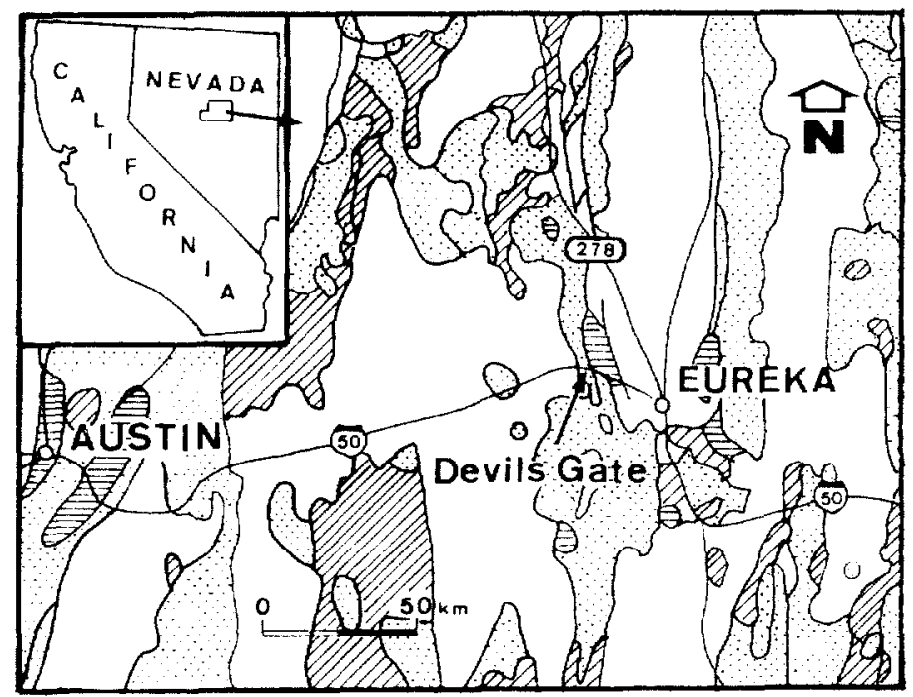

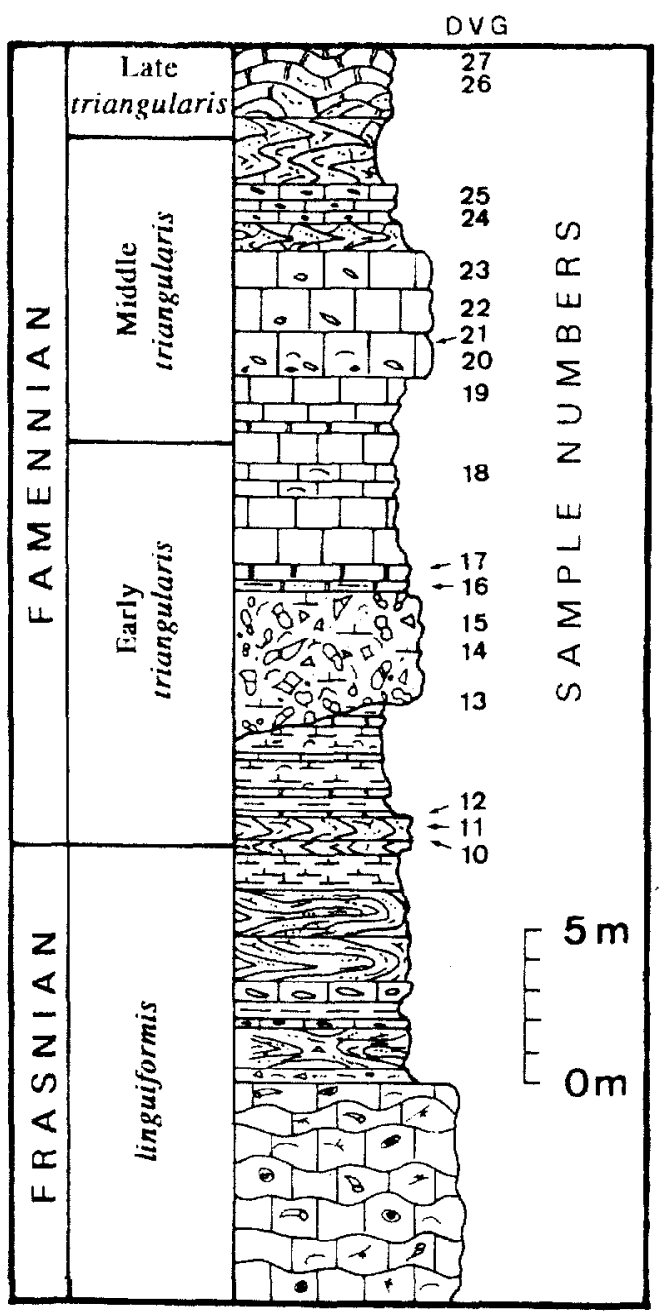

Figure 2. Lithology of the Devils Gate Limestone across the Frasnian-Famennian boundary at Devils Gate and location of samples (after Sandberg et al., 1988).

Colonne lithologique du Calcaire de Devils Gate à la limite des étages Frasnien et Famennien et localisation des échantillons ( $d$ 'après Sandberg et al., 1988). 
3000 valves, carapaces and fragments of ostracods were extracted. Only three samples (DVG10-DVG12) failed to produce ostracods. The absence of ostracods in these samples is undoubtedly related to the rapid sedimentation rate prevailing close to the FFB. According to Sandberg et al. (1988), the $10 \mathrm{~m}$ of shales, calcareous mudstones and argillaceous limestones containing large flows of carbonate-rich siltstones overlapping the FFB at Devils Gate were deposited rapidly. This has been confirmed by the discovery of very disseminated silicified ostracod carapaces in the Frasnian part of these turbiditic beds (Casier and Lethiers, 1998b).

The ostracod fauna is very rich and diversified in the base of the Famennian at Devils Gate. Fifty-nine ostracod species belonging to a shelf assemblage have been recognised (tables I and II) and, with the exception of 14 'lazarus' species sensu Flessa and Jablonski (1983) and Jablonski (1986), all are figured herein (figures 3 and 4).

\section{Famennian ostracod fauna from the chaotic bed}

In the 5-m-thick debris-flow limestone bed overlaying the FFB (samples DVG13-DVG15), ostracods are exceptionally abundant but moderately diversified. This bed is characterised by the chaotic arrangement of large and small rounded to jagged blocks of shallow water carbonate rocks, and its emplacement is supposed to be due to a tsunami generated by the breakup of the carbonate platform (Sandberg et al., 1988). Twenty-one species occur in this bed of which only 2 (3?) are 'lazarus' species. The Kloedenellacea (genera Knoxiella, Indivisia, Marginia) and the polymorphic Knoxiella? rauseri (ISCHIGOVA, 1977) represent the bulk of ostracods in this bed in which we have locally found numerous Gastropnda. Such an ostracod assemblage, characterised by the great abundance of some rare species, indicates shallow marine and more or less restricted water conditions. The occurrence of reworked Late Frasnian conodonts (Sandberg et al., 1988), characteristic of a deeper water environment mixed with this ostracod assemblage at Devils Gate confirms that this bed results from the collapse of the carbonate platform margin. Assemblages characteristic of semi-restricted water conditions have also been found above the FFB in several sections of southern Belgium, the type region for the Famennian, in China (Casicr ct al., 1996, 1997) and in Poland (current study) attesting the occurrence of an important global sea-level fall close to the FFB, as established by Johnson et al. (1985).

\section{Famennian ostracod fauna above the chaotic bed}

In the overlaying well stratified limestone beds belonging to the late part of the Early triangularis conodont zone (samples DVG16-18), reworked Late Frasnian conodont (Sandberg et al., 1988) and Kloedenellacea are still abundant. Nevertheless, the sudden occurrence of eight other 'lazarus' species (table $n$ indicates a return to conditions prevailing in the Late Frasnian.

Finally, in the Middle and Late triangularis conodont zones, eight 'lazarus' species persist and the Kloedenellacea are more rare. The ostracod assemblage of these beds is indicative of well oxygenated shelf water environments below the level of wave action, and generally below storm wave base.

Table I. Famennian ostracods (triangularis conodont zones) from the Devils Gate Pass section: distribution of species crossing the Frasnian/Famennian boundary (= 'lazarus' species).

Les Ostracodes famenniens de la coupe du col de Devils Gate : distribution des espèces traversant la limite des étages Frasnien et Famennien (= espèces "lazares").

\begin{tabular}{|c|c|c|c|c|c|c|c|c|c|c|c|c|c|c|}
\hline Devils gate: Lazarus Ostracod species & 13 & 14 & 15 & 16 & 17 & 18 & 19 & 20 & 21 & 22 & 23 & 24 & 25 & 27 \\
\hline Microcheilinella cf. peculiaris Rozhdest \& Netchaeva, 1972 & $?$ & & & - & & & & & - & & & & & \\
\hline Knoxiella? rauseri (Tschigova, 1977$)$ & - & - & - & - & - & - & - & - & - & - & - & - & - & $?$ \\
\hline Bairdiacypris martinac Casier \& Lethicrs, 1997 & & & $\cdot$ & - & & & & & - & & & - & & \\
\hline Decoranewsomites angelicus Casier \& Lethiers, 1997 & & & & - & & & & & • & & & - & & \\
\hline Kozlowskiella lazarei Casier \& Lethiers, 1997 & & & & - & & & & & & & & & & \\
\hline Bairdiocypris n. sp. A Casier \& Lethiers, 1997 & & & & - & & & & & & & & & & \\
\hline Bairdia (B.) cf. fabaeformis Polenova, 1953 sensu Lethiers, 1981 & & & & - & & & & & & & & & & \\
\hline Westmontia devilensis Casier \& Lethiers, 1997 & & & & - & & - & & & & & & & & \\
\hline Bairdiacypris quarziana (Fgorov, 1953) & & & & - & & & & & - & & & - & & \\
\hline Bairdiacypris anteroangulosa Casier \& Lethiers, 1997 & & & & - & & & & & & - & & - & & - \\
\hline Acratia nevadaensis Casier \& Lethiers, 1997 & & & & • & & - & - & & - & - & - & - & - & ? \\
\hline Bairdia nalivkini Egorov, 1953 & & & & & & & - & & - & & - & $\bullet$ & & \\
\hline Healdianella alba Lethiers, 1981 & & & & & & & & & - & & & & & \\
\hline Saccelatia kakisaensis Lethiers, 1981 & & & & & & & & & $?$ & & & • & & \\
\hline
\end{tabular}


Table Il. Newly arrived Famennian ostracod species (triangularis conodont zones) from the Devils Gate pass section. The third column indicates the length (in millimetres) of the figured specimens (figures 3 and 4).

Espèces nouvellement arrivantes dans le Famennien (zones à triangularis des Conodontes) de la cuupe du col de Devils Gate. La troisième colonne donne la longueur (en millimètres) des spécimens figurés (figures 3 et 4).

\begin{tabular}{|c|c|c|c|c|c|c|c|c|c|c|c|c|c|c|}
\hline Devils gate: Newly occurring species & Length & 13 & 14 & 15 & 16 & 18 & 19 & 21 & 22 & 23 & 24 & 25 & 26 & 27 \\
\hline 1 Aparchites sp. A & 0.52 & - & & & & & & & & & & & & \\
\hline 2 Knoxiella?sp. A & 0.69 & - & & & & & & & & & & & & \\
\hline 3 Bairdia sp. Blumenstengel, 1965 sensu Lethiers, 1971 & 0.70 & - & & & & & & & & & & & & \\
\hline 4 Bairdia diurtjulensis Rozhdestvenskaja, 1972 & 1.32 & - & & & & & & & & & & & & \\
\hline 5 Spinobairdia sp. A & 0.89 & - & & & & & & & & & & & & \\
\hline 6 Indivisia baschkirica Rozhdestvenskaja \& Tschigova, 1972 & 0.73 & - & & - & & ? & & & & & - & & & \\
\hline 7 Acratia sp. C, aff. clinata Blumenstengel, 1965 & 0.80 & - & & - & & - & & & & & - & & & \\
\hline 8 Bairdia manifesta Rozhdestvenskaja \& Tschigova, 1972 & $0.89 \& 0.93$ & - & $?$ & & - & - & - & - & & & - & & - & \\
\hline 9 Marginia cf. ivanovae Tschigova, 1977 & 0.86 & - & & & - & - & & & & - & $\bullet$ & - & • & \\
\hline 10 Cytherellina obusa Lethiers, 1976 & 0.65 & - & & & • & - & & - & - & & - & & & - \\
\hline 11 Bairdia cf. eleziana Egorov, 1953 & 0.60 & - & & & & & - & - & - & - & - & & - & - \\
\hline 12 Acratia sp. D, aff. silincula Polenova, 1953 & $0.64 \& 0.69$ & - & & - & - & & - & - & & - & - & & & $?$ \\
\hline 13 Egorovia sp. A, aff. longituda McGill, 1969 & 0.70 & • & & - & - & - & & & & - & - & & & ? \\
\hline 14 Rozhdestvenskayites sp. A & 1.06 & & & - & & & & & & & & & & \\
\hline 15 Bairdia sp. A & 0.89 & & & - & & & & & & & & & & \\
\hline 16 Selebratina cf. rjausjakensis Tschigova, 1977 & 0.46 & & & - & & & $?$ & & & & & & & \\
\hline 17 Cytherellina nov. sp. A & 0.99 & & & - & & & & & & & - & & & \\
\hline 18 lefina nov.sp. A & 0.39 & & & - & - & - & - & - & & - & - & $?$ & & - \\
\hline 19 Acratia sp. A, aff. gassanovae Egorov, 1953 & 0.52 & & & & - & & & & & & & & & \\
\hline 20 Mauryella nov. sp. A & 0.36 & & & & - & & & & & & & & & \\
\hline 21 Aechmina?sp. A & 0.49 & & & & - & & & & & & & & & \\
\hline 22 Indivisia?sp. A & 0.39 & & & & - & & & & & & & & & \\
\hline 23 "Acratia" sp. 1 sensu Lethiers, 1981 & 0.49 & & & & - & & & & & & & & & \\
\hline 24 Bairdia cf. confragosaeformis Lethiers, 1981 & 0.98 & & & & - & & & & & & & & & \\
\hline 25 Kloedenellitina? sp. A & 0.67 & & & & - & - & & & & & & & & \\
\hline 26 Acratia subelongata Rozhdestvenskaja, 1972 & 0.48 & & & & - & & & & ? & & - & & & \\
\hline 27 Eriella? sp. B & 0.50 & & & & - & - & & & & - & - & & & \\
\hline 28 Honorites?sp. A & 0.56 & & & & & - & & & & & & & & \\
\hline 29 Evlanella n. sp. A, aff. sokolovi Tschigova, 1977 & 0.74 & & & & & - & & & & & & & & \\
\hline 30 Gravia (Gravia) cf. aculeata Polenova, 1953 & 0.79 & & & & & - & & & & & & & & \\
\hline 31 Bairdiacypris?sp. B & 0.89 & & & & & - & & - & & & & & & \\
\hline 32 Marginia? macgilli (Rozhdestvenskaja, 1972) & $0.43 \& 0.73$ & & & & & - & & & & & - & - & & \\
\hline 33 Famenella bisangulata Lethiers, 1982 & 0.70 & & & & & - & • & - & - & & - & & & - \\
\hline 34 Bairdiacypris sp. A, aff. quarziana (Egorov, 1953) & 0.96 & & & & & & • & & & & - & & - & \\
\hline 35 Gravia (Gravia) sp. B, aff. levinsoni (Gibson, 1955) & 0.60 & & & & & & • & - & • & & • & & & ? \\
\hline 36 Cavellina?sp. B & 0.43 & & & & & & & - & & & & & & \\
\hline 37 Bairdia nuv. sp. A & 0.53 & & & & & & & - & & & & & & \\
\hline 38 Praepilatina sibirica Buschmina, 1975 & 0.30 & & & & & & & - & & & & & & \\
\hline 39 Sulcella (Postsulcella) nov. sp. A & 0.33 & & & & & & & - & & & & & & \\
\hline 40 Samarellan. sp. A & 0.33 & & & & & & & - & & & & & & \\
\hline 41 Bairdia sp. B, aft. subeleziana Polenova, 1953 & 0.43 & & & & & & & - & & & • & & & \\
\hline 42 Marginia sp. A & 0.40 & & & & & & & - & & & & & - & \\
\hline 43 Acratia sp. B, aff. schelonica Egorov, 1953 & 0.68 & & & & & & & & - & & & & & \\
\hline 44 Cavellina? sp. A, aff. dushanensis SHI, 1964 & 0.52 & & & & & & & & - & - & & & & \\
\hline 45 Coryellina sp. B, aff. sanctacrucensis Olempska, 1979 & 0.83 & & & & & & & & & & - & & & \\
\hline
\end{tabular}


Figure 3. Newly occurring Famennian ostracod species (triangularis conodont zones) from the Devils Gate Pass section. (a) = lateral and (b) = dorsal (except 23b and $44 b=$ ventral) views of the same specimen (except for 8 , 12 and $32=2$ specimens). Species determination and length $(\mathrm{mm})$ : see table $I I$. Specimen deposited in the micropalaeontology collection of the Belgian royal Institute of natural Sciences (Collection numbers: IRScNB $n^{\circ}$ b3405 to b3452).

Espèces nouvellement arrivantes dans le Famennien (Zones à triangularis des Conodontes) de la coupe du col de Devils Gate. (a) $=$ vue latërale et $(b)=$ vue dorsale (à l'exception de $23 \mathrm{~b}$ et $44 \mathrm{~b}=$ vues ventrales) du même spécimen là l'exception de 8,12 et $32=$ deux spécimens differents). Determination et longueur $(\mathrm{mm})$ : voir tableau II. Les spécimens sont déposés dans la collection de micropaléontologie de l'Institut royal des sciences naturelles de Belgique (numéros de collection : IRScNB n b3405 à b3452).

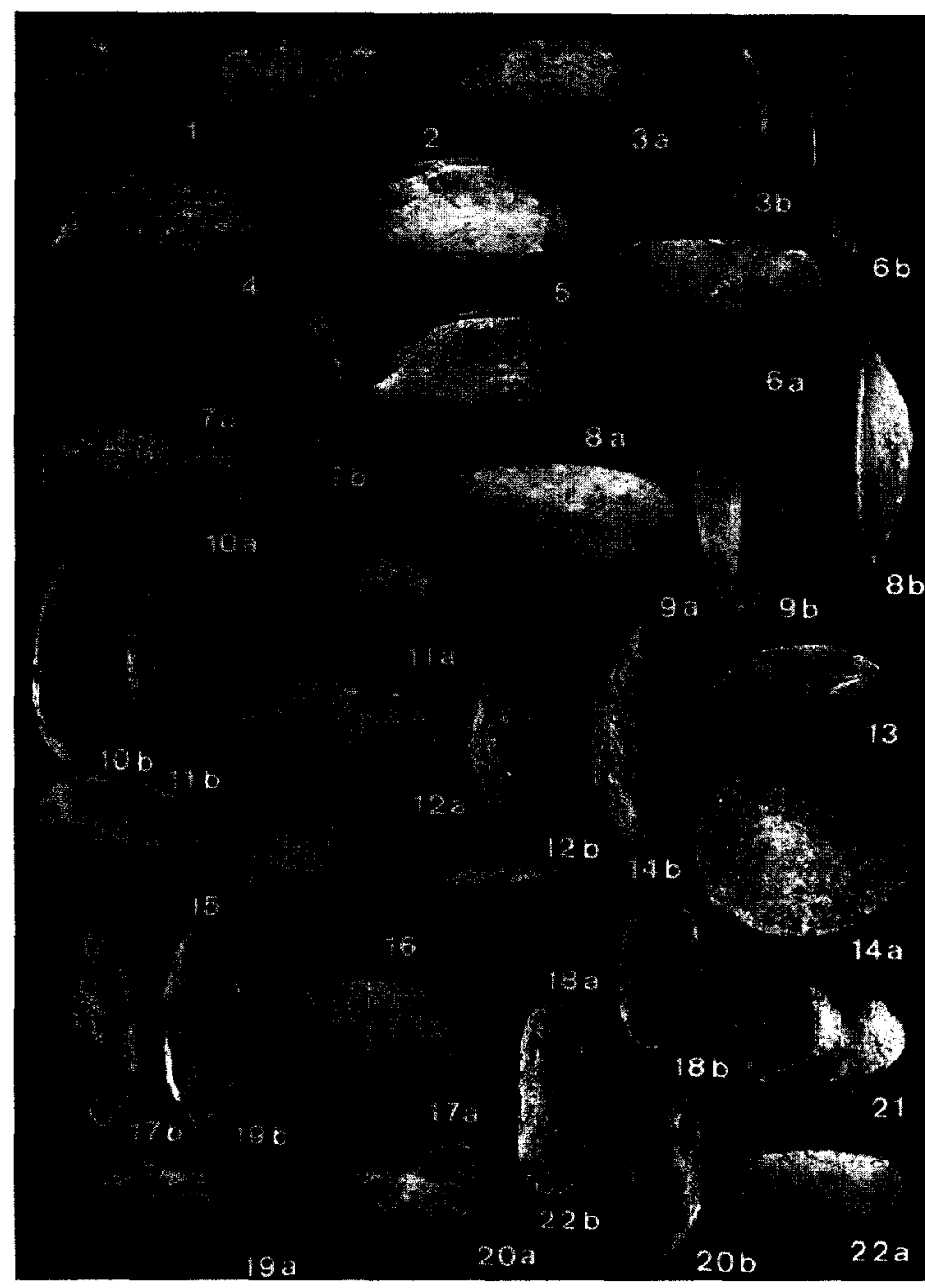

\section{Interpretation}

The ostracod distribution in the lowest part of the Famennian at Devils Gate is greatly influenced by regional sedimentological factors principally induced by a drastic worldwide eustatic sea-level fall. The increase in the sedimentation rate is responsible for the absence or perhaps for the great dissemination of ostracods close to the FFB. Abundant ostracods characteristic of shallow marine environments mixed with reworked conodonts typical of a deeper water environment give evidence for a dramatic environmental change; the collapse of the platform margin. The majority of 'lazarus' species appears higher in the section, probably when environmental conditions returned to normal.

The recovery of the ostracod fauna at Devils Gate seems to differ from the FFB GSSP at Coumiac and from the Steinbruch Schmidt auxiliary section (Casier et al., 1999; Lethiers and Casier, 1999) where 'lazarus' species recover and new species also appear gradually together. Extinction of ostracods in these two sections are linked to the incursion of hypoxic waters in shallow marine environments responsible for the deposition of the so-called Upper
Kellwasser horizon. Until now, no ostracod assemblage characteristic of oxygen depleted water conditions (= Myodocopid ecotype) has been identified at Devils Gate, either in the Late Frasnian (contrary to our previous statement in Casier et al., 1996) or in the Early Famennian. Consequently, there is no proof that the anoxia is responsible for the disappearance of more than $75 \%$ of the ostracod fauna in this section as is the case in several European sections.

Many Famennian ostracod species, 'lazarus' species included, are known or related to species previously described from the Russian Platform. This means that intensive exchanges, with or without speciation, took place between these two areas via the Western Canadian platform, during or just after the FF event.

\section{Conclusion}

The extinction of numerous ostracods close to the FFB in the Devils Gate Pass section is certainly related to a global sea-level fall responsible for the collapse of the 


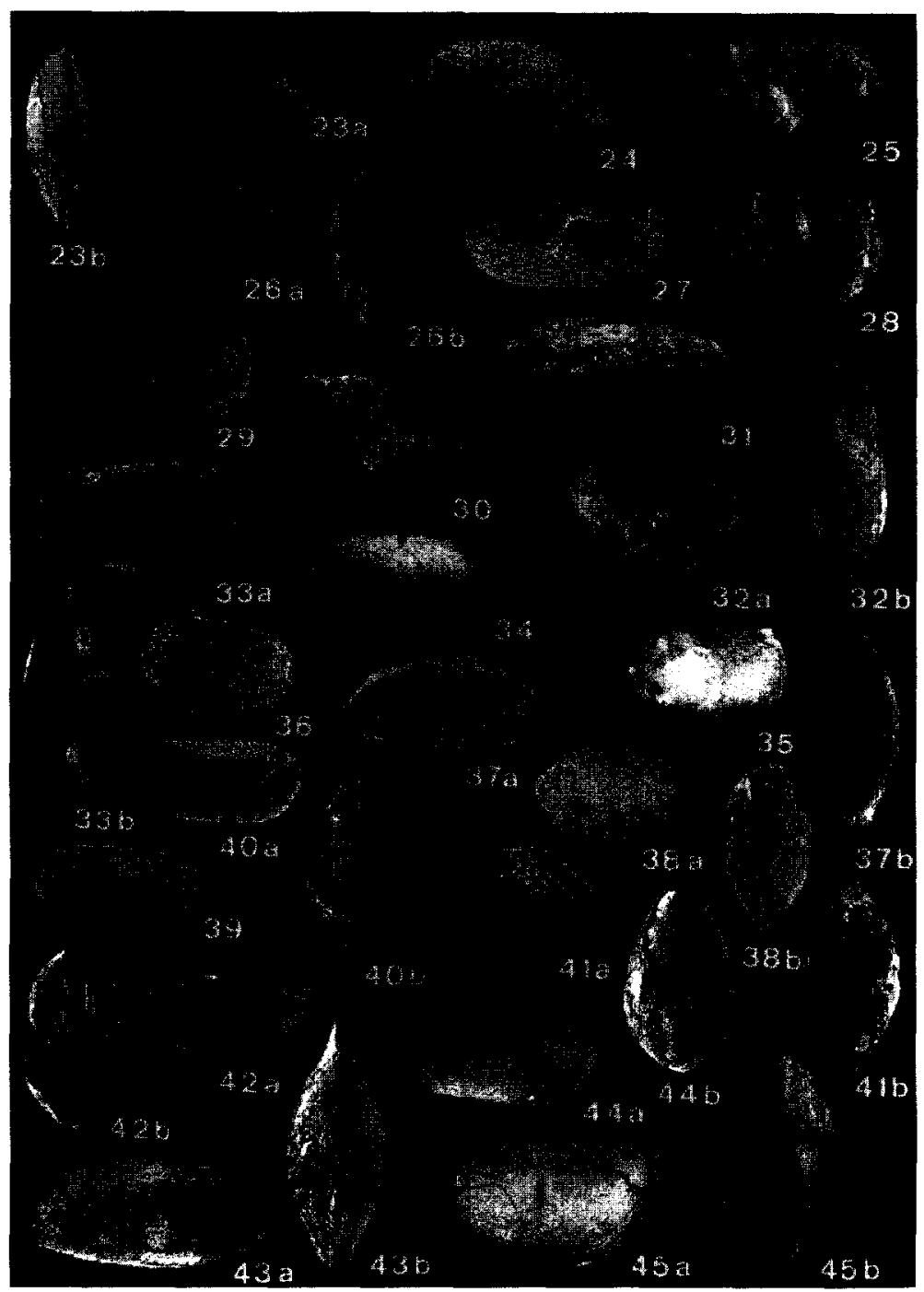

Figure 4. Newly occurring Famennian ostracod species (triangularis conodont zones) from the Devils Gate Pass section (continuation).

Espèces nouvellement arrivantes dans le Famennien (Zones à triangularis des Conodontes) de la coupe du col de Devils Gate (suite). carbonate platform margin. A reorganisation of the global oceanic circulation induced by plate tectonics might be an other important factor of extinction at Devils Gate (Copper, 1986).

\section{Version abrégée}

\section{Introduction}

La recolonisation des biotopes après une extinction en masse constitue un problème aussi important à comprendre que l'extinction elle-même. Celle qui a eu lieu à la limite des étages Frasnien et Famennien est particulièrement sévère et constitue une des crises les plus sérieuses du monde vivant (Raup et Sepkoski, 1982 ; Sepkoski, 1990), Dans la cólcbre coupe du col de Devils Gate (Sandberg et Poole, 1977; Sandberg et al., 1988, 1989, 199\%), au Nevada, elle apparât clairement. Plus de $75 \%$ des 70 espèces d'Ostracodes reconnues dans la partie sommitale du Frasnien disparaissent au cours de cet événement (Casier et al., 1996 ; Casier et Lethiers. 1997, 1998b). Afin d'étudier la recolonisation des Ostracodes dans cette coupe, nous avons récolté 18 échantillons dans les zones de conodontes à triangularis inférieure, moyenne et supérieure (figures 1 et 2). Ceux-ci ont libéré environ 3000 carapaces, valves et fragments d'Ostracodes.

\section{Les Ostracodes famenniens de Devils Gate}

59 espèces d'Ostracodes sont observees dans la base du Famennien, parmi lesquelles 14 ( tableau $D$ ) étaient dejà présentes dans le Trasnien (= espèces "lazares ", car elles manquent régionalement près de la limite $\mathrm{F} / \mathrm{F}$ ), tandis que 45 apparaissent pour la première fois (figures 3 et 4 ; tableau In.

Les trois premiers échantillons (DVG10 à DVG12), récoltés dans les shales surmontant la limite Frasnien-Famennien, n'ont pas fourni d'Ostracodes. Les trois suivants (DVG13 à DVG15). prélevés dans une brèche de $5 \mathrm{~m}$ d'épaisseur, ont par contre livré une faune extrêmement riche, mais peu diversifiée. Vingtet-une espèces sont présentes dans cette brèche dont 2 (3?) 
sont "lazares". Les Kloedenellacea, et en particulier lespèce Knoxiella? rauseri (Tschigova, 1977), sont particulièrement abondants dans ce niveau. Dans la base des calcaires stratifiés sus-jacents (DVG16 à DVG18), l'abondance des Ostracodes revient à la normale, les Kloedenellacea restent bien représentés et huit autres espèces "lazares " réapparaissent (tableau $D$ ). Finalement, dans les zones à triangularis moyenne et supérieure (échantillons DVG19 à DVG27), les Klocdencllacea se font beaucoup plus rares.

\section{Interprétation}

La distribution des Ostracodes dans la base du Famennien de cette coupe est influencée par des facteurs sédimentologiques locaux, induits par une importante régression marinc qui culmine dans l'extrême base du Famennien et est reconnue au niveau global (Johnson et al., 1985).

Un accroissement considérable de la vitesse de sédimentation est responsable de l'absence, ou tout au moins de la grande dissémination, des Ostracodes dans les sbales de l'extrême base du Famennien. Ensuite, une brèche épaisse a fourni un assemblage d'Ostracodes très riche, mais peu diversifié, dans lequel les Kloedenellacea abondent, indiquant un environnement peu profond, voire semi-restreint. Comme cet assemblage est associé à des conodontes frasniens remaniés en provenance de milieux plus profonds (Sandberg et al., 1988), il témoigne du démantèlement d'une plate-forme carbonatée. La plupart des espèces "lazares " apparaissent plus tard, lorsque la transgression famenienne permet le rétablissement des conditions de vie qui prévalaient dans la partie supérieure du Frasnien.

\section{Conclusions}

Le renouvellement faunique des Ostracodes à Devils Gate diffère de celui observé dans le limitotype de Coumiac (Montagne noire. France) et dans le parastratotype de la carrière Schmidt (Kellerwald, Allemagne) (Casier et al., 1999 ; Lethiers et Casier, 1999), où les nouvelles espèces et les espèces "lazares" réapparaissent progressivement et en même temps. Mais, dans ces deux coupes, le principal facteur dextinction est l'anoxie responsable du dépôt de l'horizon Kellwasser supérieur.

À Devils Gate, l'extinction correspond probablement à la chute eustatique, responsable de l'éboulement du rebord de la plate-forme carbonatée.

Acknowledgements. Partial support for this work was provided by the Belgian F.N.R.S. (grant FRFC $n^{\circ} 2.4511 .94$ ) and by the French C.N.R.S. (grant ESA 7073 and Crisevole project). We thank Pierre Bultynck of the Belgian Royal Institute of Natural Sciences, and Claude Babin of the University Lyon 1, for constructive reviews.

\section{References}

Bandel K. and Becker G. 1975. Ostracoden aus paläozoischen pelagischen Kalken der Karnischen Alpen (Silurium bis Unterkarbon), Senckenbergiana leth., 56, 1, 1-83

Casier J.-G. and Lethiers F. 1997. Les Ostracodes survivants à l'extinction du Dévonien supérieur dans la coupe du col de Devils Gate (Nevada, USA), Geobios, 30, 6, 811-821

Casier I.-G. and Lethiers F. 1998a. Ostracods Late Devonian mass extinction: the Schmidt quarry parastratotype (Kellerwald, Germany), C. R. Acad. Sci. Paris, 326, Series Ila, 71-78

Casier J.-G. and Lethiers F. 1998b. Les Ostracodes du Frasnien terminal (zone à linguiformis des Conodontes) de la coupe du col de Devils Gate (Nevada, USA), Bull. Inst. roy. Sci. nat. Belgique, Sci. de la Terre, 66, 77-95

Casier I.-G., Lethicrs F. and Clacys P. 1996. Ostracod evidence for an abrupt mass extinction at the Frasnian-Famennian boundary (Devils Gate, Nevada, USA), C. R. Acad. Sci. Paris, 322, Series lla, 415-422

Casier J.-G., Lethiers F. and Hou Hongfei 1997. Ostracodes from the Frasnian-Famennian transition beds in the Lijiaping section (Hunan, southern China), C. R. Acad. Sci. Paris, 325, Scries IIa, 433-438

Casier J.-G., Lethiers F. and Baudin F. 1999. Ostracods, organic matter and anoxic events associated with the Frasnian-Famennian boundary in the Schmidt quarry parastratotype section (Kellerwald, Germany), Geobios (in print)

Copper P. 1986. Frasnian-Famennian mass extinction and coldwater oceans, Geology, 14, 835-839

Copper P. 1994. Ancient reef ecosystem expansion and collapse, Coral Reefs, 13, 3-11

Flessa K. and Jablonski D. 1983. Extinction is here to stay, Paleobiology, 9, 4, 315-321

Jablonski D. 1986. Causes and consequences of mass extinctions: a comparative approach, in: Elliot D.K. (Ed.), Dynamics of extinction, Wiley Interscience, New York, 183-229
Johnson J., Klapper G. and Sandberg C. 1985. Devonian eustatic fluctuations in Euramerica, Bull. Geol. Soc. America, 96, 567-587

Lethiers F. and Crasquin-Soleau S. 1988. Comment extraire les microfossiles à tests calcitiques des roches calcaires dures, Rev. Micropal., 31, 1. 36-61

Lethiers F. and Casier J.-G. 1996. Les Ostracodes survivant à l'événement F-F dans le limitotype de Coumiac (Montagne noire, France), Ann. Soc. géol. Belgique, 117 (1994), 1, 137-153

Lethicrs F. and Casier J.-G. 1999. Les Ostracodes du Tamennien inférieur au stratotype de Coumiac (Montagne Noire, France) : la reconquête post-événementielle, Bull. Inst. roy. Sci. nat. Belgique, Sci. de la Terre, 67 (in print)

McGhee G. 1996. The Late Devonian Mass Extinction. The Frasnian-Famemian crisis, Columbia Lniv. Press, New York, 303 p.

Raup D. and Sepkoski J. 1982. Mass extinction in the marine fossil record, Science, 215, 1501-1503

Sandberg C. and Poole F. 1977. Conodont biostratigraphy and depositional complexes of Upper Devonian cratonic-platform and continental-shelf rocks in the Western United States, in: Murphy M., Berry W. and Sandberg G. (Eds.), Western North America: Devonian, Campus Mus. Contrib. Univ. California, Riverside, 4, 144-182

Sandberg C., Morrow J. and Warme 1. 1997. Late Devonian Alamo impact event, global Kellwasser events, and major eustatic events, eastern Great Basin, Nevada and Utah, BYU Geology studies, 42, 1 , $129-160$

Sandberg C., Poole F. and Johnson I. 1989. Upper Devonian of Western United States, in: McMillan N., Embry A. and Glass D. (Eds.) Devonian of the World, Canadian Soc. Petrol. Geol., 14, 1, 183-220

Sandberg C., Ziegler W., Dreesen R. and Butler J. 1988. Late Frasnian mass extinction: Conodont event stratigraphy, global changes, and possible cause, Cour. Forsch.-inst. Senckenberg, 102 , 267-297

Sepkoski J. 1990. The taxonomic structure of periodic extinction, Spec. Pap. Geol. Soc. America, 247, 33-44 